Biol. Stud. 2021; 15(4): 37-48 • DOI: https://doi.org/10.30970/sbi.1504.673

www.http://publications.Inu.edu.ua/journals/index.php/biology

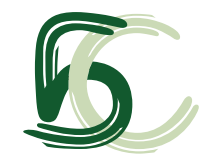

UDC: $577.35+577.352$

\title{
EFFECT OF A NOVEL THIAZOLE DERIVATIVE AND ITS COMPLEX WITH A POLYMERIC CARRIERS ON THE ACTIVITY OF ANTIOXIDANT ENZYMES IN MURINE LYMPHOMA CELLS
}

\author{
M. V. Popovych \\ N. E. Mitina ${ }^{2}$, O. S. Zaichenko ${ }^{2}$, A. M. Babsky@ \\ ${ }_{1}^{1}$ Ivan Franko National University of Lviv, 4, Hrushevskyi St., Lviv 79005, Ukraine \\ ${ }^{2}$ Lviv Polytechnic National University, 9 Yura Sqr., Lviv 79013, Ukraine
}

Popovych, M. V., Shalai, Ya. R., Mandzynets, S. M., Mitina, N. E., Zaichenko, O. S., \& Babsky, A. M. (2021). Effect of a novel thiazole derivative and its complex with polymeric carriers on the activity of antioxidant enzymes in murine lymphoma cells. Studia Biologica, 15(4): 37-48 • DOI: https://doi. org/10.30970/sbi.1504.673

Background. Previous studies have shown a pronounced cytotoxic effect of thiazole derivatives in combination with polymeric carriers on tumor cells. At the same time, the derivatives were not cytotoxic against non-cancerous cells in vitro. It was shown that thiazole derivatives at concentrations of 10 and $50 \mu \mathrm{M}$ affected the prooxidant and antioxidant systems of lymphoma cells in vitro. The aim of this work was to study the effect of the complex of thiazole derivative $\mathrm{N}$-(5-benzyl-1,3-thiazol-2-yl)-3,5-dimethyl-1-benzofuran-2carboxamide (BF1) in combination with polymeric carriers poly(VEP-co-GMA)-graftmPEG (Th1), poly(PEGMA) (Th3) and poly(PEGMA-co-DMM) (Th5) on the antioxidant defense system of the NK/Ly cell in vitro.

Materials and Methods. The experiments were performed on white wild-type male mice with grafted NK/Ly lymphoma. Tumor cells were inoculated into mice intraperitoneally. Ascites was drained from the abdominal cavity of anaesthetized mice with a sterile syringe on the 7th-10th day after inoculation. Investigated compounds BF1, BF1 + Th1 (Th2, Th12), BF1 + Th3 (Th4, Th14), BF1 + Th5 (Th6, Th16) at a final concentration of $10 \mu \mathrm{M}$ were added to the lymphoma samples and incubated for $10 \mathrm{~min}$; the activity of antioxidant enzymes was determined according to the techniques described previously.

Results. It was found that all the studied complexes based on thiazole derivative BF1 and polymeric carriers poly (VEP-co-GMA)-graft-mPEG (Th2, Th12), poly (PEGMA) (Th4, Th14) and poly (PEGMA-co-DMM) (Th6, Th16) at a concentration of $10 \mu \mathrm{m}$

( 2021 M. V. Popovych et al. Published by the Ivan Franko National University of Lviv on behalf of Біологічні Студії / Studia Biologica This is an Open Access article distributed under the terms of the Creative Commons Attribution 4.0 License which permits unrestricted reuse, distribution, and reproduction in any medium, provided the original work is properly cited.

ISSN 1996-4536 (print) • ISSN 2311-0783 (on-line) • Біологічні Студії / Studia Biologica • 2021 • Том 15 / № 4 • С. 37-48 
increased the activity of SOD, while the activity of CAT and GPX were reduced compared to control. Complexes Th2, Th12 and Th4 increased the significance of the BF1 influence on lymphoma cells from $P<0.05$ to $P<0.01$. Pure polymeric carriers did not affect the level of the antioxidant defense system enzymes.

Conclusions. Thus, it was found that the polymeric carriers in combination with thiazole derivative BF1 increased the significance of thiazole derivative BF1 influence on the activity of the antioxidant defense system of lymphoma cells, while pure polymeric carriers did not affect the activity of SOD, CAT or GPX. The results of this work can be used for further studies of complexes of thiazole derivative and PEG-containing polymeric carriers as potential antitumor drugs.

Keywords: lymphoma, thiazole derivative, polymeric carriers, polyethyleneglycol, antioxidant defense system

\section{INTRODUCTION}

The intensity of free radical processes is determined by the balance of prooxidant and antioxidant reactions in cells. Under normal physiological conditions, the concentration of reactive oxygen species (ROS) in tissues is low, but in different pathological conditions, the formation of ROS intensifies while the activity of protective systems of the cell decreases causing apoptosis or necrosis. As a results of an elevated level of ROS in cells, the activity of the antioxidant defense enzymes increases allowing cells to survive under these conditions (Snezhkina et al., 2019; Perillo et al., 2020). A number of defense mechanisms are present in the body to prevent the formation of ROS and the damage resulting from their presence. Enzymes such as superoxide dismutase (SOD), catalase (CAT) and glutathioneperoxidase (GPX) is involved in inactivation of existing ROS.

Nowadays, there are no universal chemotherapeutic drugs, as most of them have a number of disadvantages, in particular, low therapeutic effect, high toxicity, lack of selectivity and side effects (Sutradhar \& Amin, 2014). Therefore, the search for new antitumor compounds with lower toxicity, high selectivity and therapeutic effect is an urgent problem of chemotherapy.

A cytotoxic effect of the investigated thiazole derivatives on cell lines of melanoma, glioblastoma, hepatocarcinoma, leukemia cells has been established (Finiuk et al., 2017). It was found that thiazole derivatives of $\mathrm{N}$-(5-benzyl-1,3-thiazol-2-yl)-3,5dimethyl-1-benzofuran-2-carboxamide (BF1) changed prooxidant-antioxidant balance, in particular increased the activity of SOD and inhibited CAT and GPX activity in NemethKellner lymphoma (NK/Ly) cells (Shalai et al., 2019).

However, thiazole derivatives have a low aqueous solubility that can limit their efficiency. Besides, many anticancer agents share similar issues affecting safe and effective delivery to the localization of tumors (Amreddy et al., 2018).

Nanoparticles (NP) can play a significant role as a solvent-based drug delivery system. In addition, they have many other specific advantages, such as enhanced of permeability, stability, biocompatibility and targeted delivery of anticancer agents to overcome cancer-related drug resistance (Sutradhar \& Amin, 2014; Dadwal, Baldi, \& Kumar Narang, 2018). Numerous types of NPs, both organic and inorganic, have already been extensively used in the clinical treatment of several cancer types, including pancreatic, breast, ovarian, and prostate cancers (Alimoradi., Greish, BarzegarFallah, Alshaibani, \& Pittalà, 2018; Wang et al., 2018; Zhao et al., 2019).

ISSN 1996-4536 (print) • ISSN 2311-0783 (on-line) • Біологічні Студії / Studia Biologica • 2021 • Том 15 / № 4 • C. $37-48$ 
Polyethylene glycol (PEG), as a water-soluble polymer, is one the most widely used non-ionic polymer in the field of polymer-based drug delivery (Knop, Hoogenboom, Fischer, \& Schubert, 2010). Numerous clinical trials investigated PEGylated low molecular weight drugs/liposomal derivatives/thermo-sensitive conjugates and nanoparticles as efficient anticancer therapy. For example CALLA 01 (PEGylated cyclodextrin nanoparticle) is in clinical phase I for solid tumors (Lee, Yoon, \& Cho, 2013). It was reported, that thiazole derivatives complexes with PEG-based polymeric carriers caused apoptotic-like changes in lymphoma cells (Popovych et al., 2021).

The purpose of this work was to investigate the effect of thiazole derivative BF1, conjugated with polymeric-containing carriers poly(VEP-co-GMA)-graft-mPEG (Th1), poly(PEGMA) (Th3) and poly(PEGMA-co-DMM) (Th5) on the activity of enzymes of the antioxidant defense system of lymphoma cells.

\section{MATERIALS AND METHODS}

The study was performed on white wild-type male mice ( $n=45 ; 20-30 \mathrm{~g}$ ) with grafted NK/Ly lymphoma. All manipulations with animals were conducted in accordance with General Ethical Principles of Experimentation on Animals approved by the First National Congress on Bioethics (Kyiv, Ukraine, 2001) and the European Convention for the Protection of Vertebrate Animals used for Experimental and Other Scientific Purposes (Strasbourg, France, 1985), as well as approved by the Ethics Committee of Ivan Franko National University of Lviv, Ukraine at the beginning of the research (Protocol of 01.05.2021 No 19-05-2021) and after the completion of the study (Protocol of 01.12.2021 No 26-12-2021).

Ascites tumor cells were passaged by intraperitoneal inoculation of $10-15 \times 10^{6}$ cells to mice. Ascites was drained from the abdominal cavity of anaesthetized mice with sterile syringe on 7-10 day after the inoculation. For determination of the antioxidant defense systems activity, enzymes ascites from 5 different mice were used for each group of experiments.

The initial $10 \mu \mathrm{M}$ solution of thiazole derivative BF1 was synthesized at the Department of Organic Chemistry of Ivan Franko Lviv National University and the PEGcontaining carriers were synthesized at the Department of Organic Chemistry of the Lviv Polytechnic National University, as described earlier (Mitina et al., 2020; Finiuk et al., 2017).

Water dispersions of polymeric carriers (PC) on the basis of poly(VEP-co-GMA)graft-mPEG (Th1), poly(PEGMA) (Th3) and poly(PEGMA-co-DMM) (Th5) and their complexes with the BF1 derivative were prepared in two different ways: 1) PC and BF1 were dissolved in dimethyl sulfoxide (DMSO), and the solutions were subsequently transferred in water (Th2, Th4, Th6) or 2) BF1 solution in DMSO was added to PC water solution (Th12, Th14, Th16). Three groups of chemical compounds were prepared: 1st group - BF1 (10 mM), Th1 (1 g/100 mL) Th2 and Th12 (Th1 $(1 \mathrm{~g} / 100 \mathrm{~mL})+$ BF1 (0.03 g/100 mL) prepared in two different techniques), 2nd group - BF1 (10 mM), Th3 $(1 \mathrm{~g} / 100 \mathrm{~mL})$, Th4 and Th14 (Th3 $(1 \mathrm{~g} / 100 \mathrm{~mL})+$ BF1 $(0.03 \mathrm{~g} / 100 \mathrm{~mL}))$ prepared in two different techniques) and 3rd group - BF1 (10 mM), Th5 $(1 \mathrm{~g} / 100 \mathrm{~mL})$, Th6 and Th16 (Th5 $(1 \mathrm{~g} / 100 \mathrm{~mL})+$ BF1 $(0.03 \mathrm{~g} / 100 \mathrm{~mL}))$ prepared in two different techniques) and added to the lymphoma homogenate with duration of incubation $10 \mathrm{~min}$. Other explanations see in the Table.

ISSN 1996-4536 (print) • ISSN 2311-0783 (on-line) • Біологічні Студії / Studia Biologica • 2021 • Том 15 / № 4 • С. 37-48 
Structure of the investigated substances used in experiments

Структура досліджуваних речовин, які використовували в дослідах

\begin{tabular}{l|c|c|c|c}
\hline Name of sample & Thiazole derivative & Polymeric carrier & $\begin{array}{c}\text { Complexes } \\
\text { Preparing }\end{array}$ & $\begin{array}{c}\text { Preparing } \\
\text { techniques 2 }\end{array}$ \\
\hline Control & - & - & - & - \\
BF1 & + & - & - & - \\
Th1, Th3, Th5 & - & + & - & - \\
Th2, Th4, Th6 & - & - & + & - \\
Th12, Th14, Th16 & - & - & - & + \\
\hline
\end{tabular}

To measure the activity of SOD, CAT and GSH-Px, lymphoma cell samples were frozen in a freezer chamber to $-20{ }^{\circ} \mathrm{C}$ and subsequently used for investigation. Superoxide dismutase activity was measured by the method described by V. Kostyuk et al. and enzymatic activity was expressed as unit $\mathrm{SOD} / \mathrm{mg}$ protein (Kostyuk, Potapovich, \& Kovaleva, 1990). Catalase activity was measured spectrophotometrically by the method described by M. Korolyuk et al. and the activity of CAT was expressed in nmoles of $\mathrm{H}_{2} \mathrm{O}_{2}$ /min $\times$ mg of protein (Korolyuk, Ivanova, Mayorova, \& Tokaryev, 1998). Glutathionperoxidase (GPX) activity was measured by the method of Moin and expressed in $\mu \mathrm{M}$ of $\mathrm{G}-\mathrm{SH} / \mathrm{min} \times \mathrm{mg}$ of protein (Moin, 1986). Protein concentration in each specimen was determined by the method of O. Lowry et al. (Lowry, Rosebrough, Farr, \& Randall, 1951).

The MS Excel-2013 and Statistica programs were used for statistical analysis of obtained results. To assess the reliability of difference between statistical characteristics of two alternative sets of data, Student's coefficient and Mann-Whitney test were calculated. To determine statistically significant differences between the means of independent investigation groups, one-way analysis of variance (ANOVA) was used. The difference was considered to be significant at $\mathrm{P}<0.05$.

\section{RESULTS AND DISCUSSION}

ROS play a vital role in fundamental physiological processes, such as production of hormones, modulation of protein functions, regulation of cell signaling and inflammation, but in many pathological states their level are over elevated and can induce the non-specific damage of DNA, some proteins and lipids and increase the risk of mutating cellular DNA. Antioxidant enzymes including SOD, CAT and GPX are highly specific, with high affinities and rates of reaction that decompose ROS with a high efficacy.

It was reported that thiazole derivatives produce their cytotoxic effect through the effect on the activity of antioxidant system (Shalai et al., 2019), while polymeric carriers are widely used to improve the efficiency and water solubility of antitumor drugs, increase their biocompatibility and delivery. Thus, the aim of our work was to evaluate the effect of PEG-containing PCs and their complexes with thiazole derivative BF1 on the activity of key enzymes of the antioxidant system in lymphoma cells.

Superoxide dismutase is an enzyme that converts superoxide $\left(\mathrm{O}_{2}{ }^{--}\right)$to $\mathrm{H}_{2} \mathrm{O}_{2}$.

Figure 1 represents the results of SOD activity of the investigated substance BF1, pure polymers poly(VEP-co-GMA)-graft-mPEG (Th1), poly(PEGMA) (Th3) and 
poly(PEGMA-co-DMM) (Th5) and complexes of the substance with the polymers (Th2, Th12, Th4, Th14, Th6 and Th16) in NK/Ly cells. The control level of SOD activity in lymphoma was in the range of $433-511$ active units/min $\times$ mg of protein.

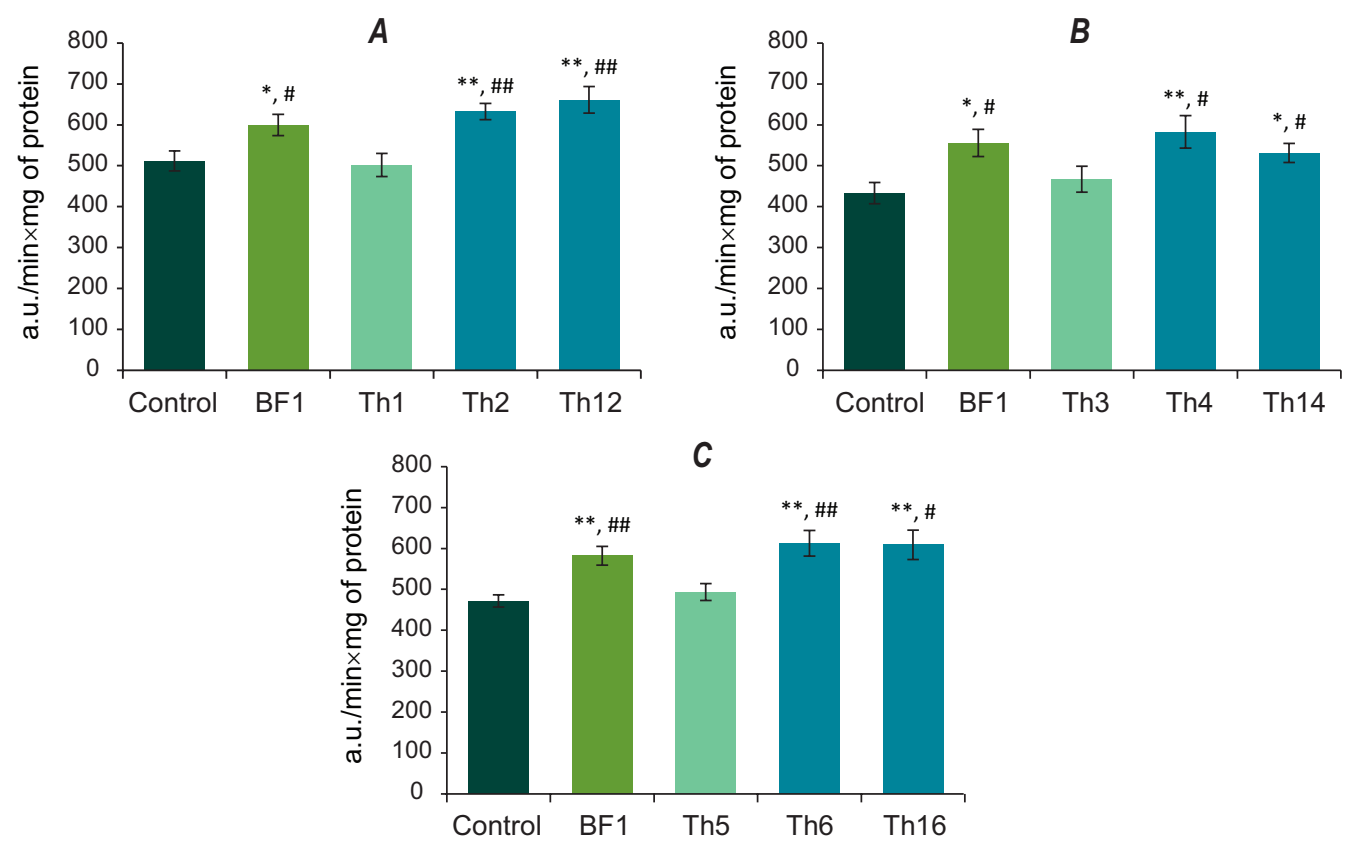

Fig. 1. The effect of thiazole derivative (BF1), pure polymeric carriers (Th1, Th3, Th5) and complexes of BF1 with PCs (Th2, Th4, Th6 and Th12, Th14, Th16) on the activity of superoxide dismutase in lymphoma cells. $(\boldsymbol{A})$ The left panel represents the effects of BF1, the pure polymer based on poly(VEP-co-GMA)graft-mPEG (Th1) and its complexes with BF1 (Th2 and Th12) compared to control. $(\boldsymbol{B})$ The middle graph represents the effects of BF1, the pure polymer based on poly(PEGMA) (Th3) and its complexes with BF1 (Th4 and Th14) compared to control. (C) The right graph represents the effects of BF1, the pure polymer based on poly(PEGMA-co-DMM) (Th5) and its complexes with BF1 (Th6 and Th16) compared to control. The control level of the enzyme activity is assumed as $100 \%$. $\mathrm{M} \pm \mathrm{m}$; $\mathrm{n}=5$. * ${ }^{*}$ - $\mathrm{P}<0.05$; ** ${ }^{* \#}-\mathrm{P}<0.01$ ( ${ }^{*}$ - for Students' -test, \# - for U-test Mann-Whitney)

Рис.1. Вплив похідного тіазолу (BF1), полімерних носіїв (Th1, Th3, Th5) і комплексів BF1 та полімерних носіїв (ПН) (Th2, Th4, Th6 and Th12, Th14, Th16) на активність супероксиддисмутази клітин лімфоми. $(\boldsymbol{A})$ На лівому графіку зображено вплив BF1, полімерного носія poly(VEP-co-GMA)-graftmPEG (Th1) і їхніх комплектів (Th2 та Th12) порівняно з контролем. (B) На середньому графіку зображено вплив BF1, полімерного носія роly(PEGMA) (Th3) та їхніх комплектів (Th4 та Th14) порівняно з контролем. (C) На правому графіку зображено вплив BF1, полімерного носія poly(PEGMA-co-DMM) (Th5) та їхніх комплектів (Th6 та Th16) порівняно з контролем. Контрольний рівень активності ензиму прийнятий за 100\%. М $\pm \mathrm{m} ; \mathrm{n}=5 .{ }^{*}$, * $-\mathrm{P}<0.05 ;{ }^{* *},{ }^{\#}-\mathrm{P}<0.01$ ( ${ }^{*}-$ для критерію Стьюдента, \# - для тесту Манна-Уітні)

BF1 significantly increased the activity of SOD after 10 min of incubation with lymphoma cells by $17 \%$ (Fig. 1 A; $\mathrm{P}<0.05$ ), 29\% (Fig. 1B; $\mathrm{P}<0.05$ ) and $23 \%$ (Fig. 1C; $\mathrm{P}<0.01)$, compared to control meaning Complexes Th2 and Th12 significant elevated the level of enzyme by $24 \%$ and $24 \%$, respectively (Fig. 1A, P <0.01). The activity of SOD significantly increased under the effect of Th4 and Th14 by $35 \%$ and $29 \%$ (Fig. 1B, $P<0.01$ and $P<0.05$ ), respectively. Both complexes Th6 and Th16) significantly elevated the level of the investigated enzyme by $29 \%$ (Fig. 1 C, $P<0.01$ and $P<0.05$ ).

ISSN 1996-4536 (print) • ISSN 2311-0783 (on-line) • Біологічні Студії / Studia Biologica • 2021 • Том 15 / № 4 • С. 37-48 
The availability of PCs in complexes Th2, Th12, Th4 were contributed to the increase in the significance of the substance effect on SOD activity. There were no significant changes in the levels of SOD after the influence of pure polymeric carriers Th1, Th3 and Th5 in lymphoma cells.

CAT catalyzes the dismutation of hydrogen peroxide $\left(\mathrm{H}_{2} \mathrm{O}_{2}\right)$ into water and molecular oxygen and frequently downregulates in tumor cells compared to normal of the same origin (Shalai, Mandzynets, Grenyukh, Finiuk, \& Babsky, 2017).

Figure 2 illustrates changes in the activity of CAT in the lymphoma cells under the action of BF1, pure PCs and their complexes. The control level of CAT activity was $0.006-0.0084 \mathrm{nmol}$ of $\mathrm{H}_{2} \mathrm{O}_{2} / \mathrm{min} \times \mathrm{mg}$ of protein. It was found that BF1 significantly reduced the activity of CAT by $11 \%$ (Fig. $2 A, P<0.05$ ), $15 \%$ (Fig. $2 B, P<0.05$ ) and $12 \%$ (Fig. 2C, $\mathrm{P}<0.05$ and $\mathrm{P}<0.01$ ) compared to control. The activity of CAT significantly decreased under the effects of Th2 and Th12 by $17 \%$ and $12 \%$ (Fig. 2A, P $<0.05$ and $\mathrm{P}<0.01$ ); Th4 and Th14 by $23 \%$ and $22 \%$ (Fig. 2B, $\mathrm{P}<0.05$ and $\mathrm{P}<0.01$ ); Th6 and Th16 $12 \%$ and $16 \%$ (Fig. 2C, P <0.05), respectively. Interestingly, a more significant influence was noticed under the action of complexes Th2, Th12 and Th4 compared to BF1 effect. Pure PCs (Th1, Th3, Th5) did not change the activity of CAT (Fig. 2).
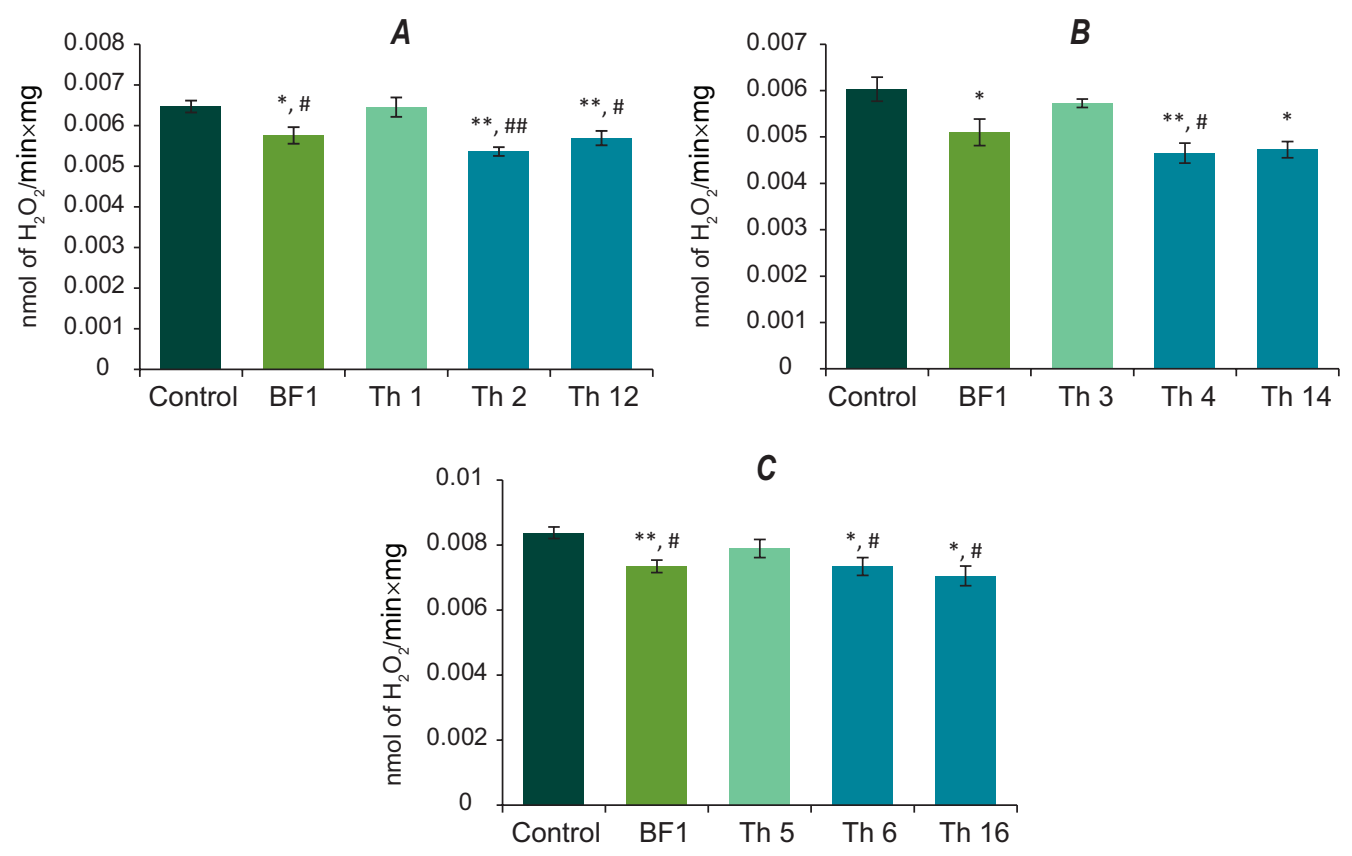

Fig. 2. Effect of thiazole derivative (BF1), pure polymeric carriers (Th1, Th3, Th5) and complexes of BF1 with PCs (Th2, Th4, Th6 and Th12, Th14, Th16) on the activity of catalase in lymphoma cells compared to control. The control level of the enzyme activity is assumed as $100 \% . \mathrm{M} \pm \mathrm{m} ; \mathrm{n}=5$. * ${ }^{*}-\mathrm{P}<0.05$; ${ }^{* *}$, \#\# - P $<0.01$ ( ${ }^{*}$ - for Students' $t$-test, \# - U-test Mann-Whitney). For further description, see Fig. 1

Рис. 2. Вплив похідного тіазолу (BF1), полімерних носіїв (Th1, Th3, Th5) і комплексів BF1 та полімерних носіїв (ПН) (Th2, Th4, Th6 and Th12, Th14, Th16) на активність каталази клітин лімфоми порівняно з контролем. Контрольний рівень активності ензиму прийнятий за $100 \%$. M \pm m; $\mathrm{n}=5$. *, \# - Р <0,05; **, \# - Р <0,01 ( пояснення див. на рис. 1

ISSN 1996-4536 (print) • ISSN 2311-0783 (on-line) • Біологічні Студії / Studia Biologica • 2021 • Том 15 / № 4 • C. 37-48 
The main function of GPX is destruction and inactivation of hydrogen peroxide and toxic oxygen compounds - hydroperoxides, using reduced glutathione (GSH) as an electron donor.

Figure 3 shows changes in the activity of GPX under the action of BF1, pure PCs and their complex. The control level of the enzyme was $1.25-3.01 \mathrm{nmol} G \mathrm{GH} / \mathrm{min} \times \mathrm{mg}$ protein. It was found that the activity of GPX significantly decreased under the action of: Th2 and Th12 by $17 \%$ and $16 \%$ (Fig. 3A, $\mathrm{P}<0.05$ and $\mathrm{P}<0.01$ ); Th4 and Th14 by $35 \%$ and $26 \%$ (Fig. 3B, $\mathrm{P}<0.05$ and $\mathrm{P}<0.01$ ); Th6 and Th16 by $48 \%$ and $47 \%$ (Fig. 3 C, $P<0.05$ and $P<0.01$ ), respectively, while BF1 significantly decreased the level of the enzyme by $21 \%$ (Fig. 3A, P $<0.05$ and $\mathrm{P}<0.01$ ), $27 \%$ (Fig. 3B, P <0.05) and $44 \%$ (Fig. $3 C, \mathrm{P}<0.05)$ vs control. Only one or three naked PCs - Th5 - significantly decreased the activity of GPX by $27 \%$ (Fig. 3 C, P <0.05) compared to control. No significant changes between BF1 and complexes were recorded, but the influence on the action of GPX was more significant under the action of complex Th4.
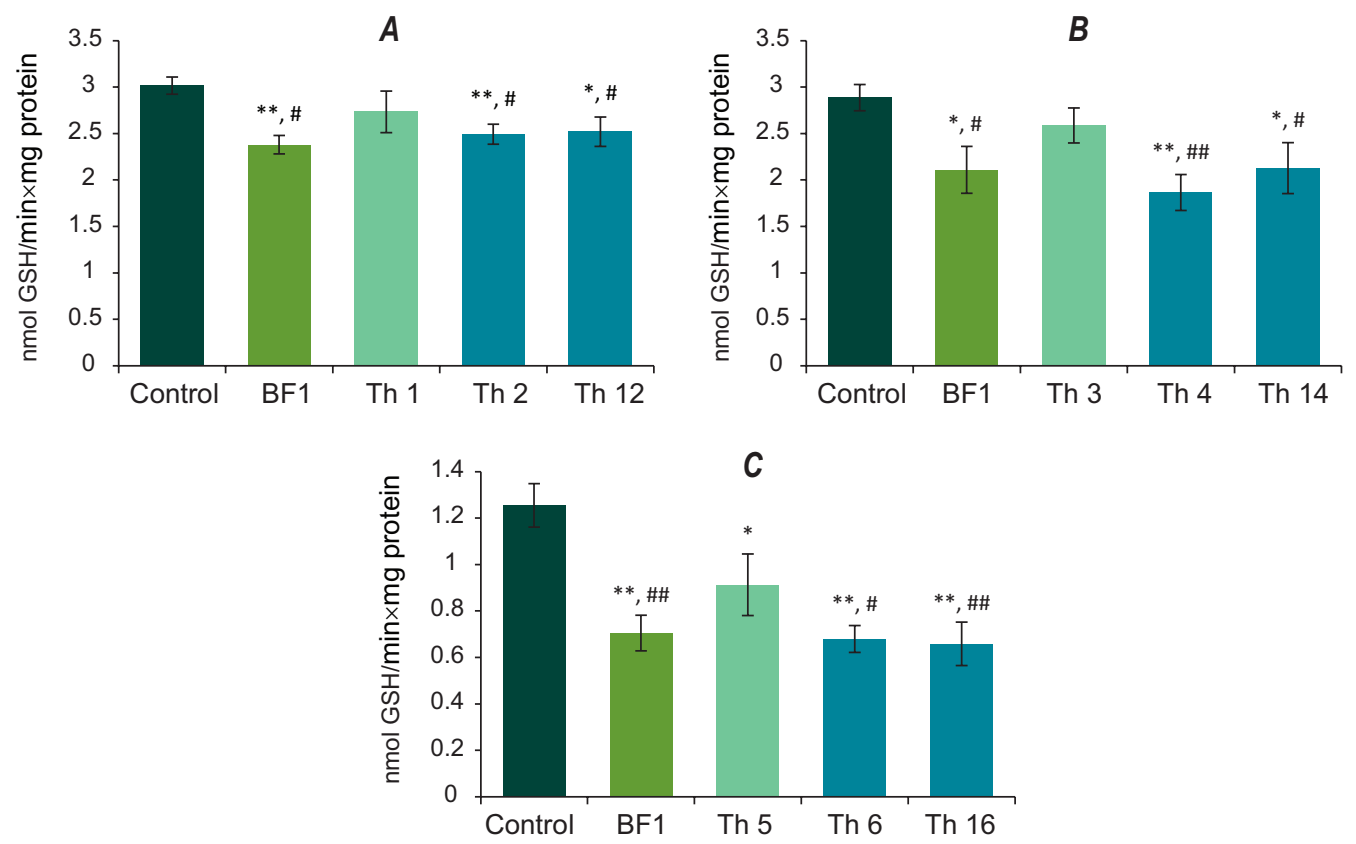

Fig. 3. The effect of thiazole derivative (BF1), pure polymeric carriers (Th1, Th3, Th5) and complexes of BF1 with PCs (Th2, Th4, Th6 and Th12, Th14, Th16) on the activity of glutathionperoxidase in the lymphoma cells compared to control. The control level of the enzyme activity is assumed as $100 \%$. M \pm $\mathrm{m} ; \mathrm{n}=5$. * ${ }^{*}$ " $-\mathrm{P}<0.05$; ${ }^{* *}$, \# $-\mathrm{P}<0.01$ ( ${ }^{*}$ - for Students' $t$-test, \# - U-test Mann-Whitney). For further description, see Fig. 1

Рис. 3. Вплив похідного тіазолу (BF1), полімерних носіїв (Th1, Th3, Th5) і комплексів BF1 та полімерних носіїв (ПН) (Th2, Th4, Th6 and Th12, Th14, Th16) на активність глутатіонпероксидази клітин лімфоми порівняно з контролем. Контрольний рівень активності ензиму прийнятий за $100 \%$. M $\pm \mathrm{m}$; n = 5. * , * P <0,05; **, \#\#-P <0,01 (* - для критерію Стьюдента, \# - для тесту Манна-Уітні). Інші пояснення див. на рис. 1

Thiazole derivatives are a promising group of compounds that show their efficacy in antitumor, antiparasitic, antifungal, antimicrobial and antiproliferative activities (De

ISSN 1996-4536 (print) • ISSN 2311-0783 (on-line) • Біологічні Студії / Studia Biologica • 2021 • Том 15 / № 4 • С. 37-48 
Santana et al., 2018). Many of thiazole-containing drugs such as Abafungin, Amiphenazole, Brecanavir, Carumonam and many other are commercially available.

The main problem that limits a widespread use of thiazole derivatives as an antitumor agent is its low solubility in water and many organic solvents, which pointedly reduces their efficacy. Polymeric carriers are widely used to enhance the efficiency of biological action of drugs, improve their biocompatibility and water solubility and additionally may reduce the total toxicity, enhance the accumulation of antitumor drugs in cancer cells and tissues and improve their efficacy (Wang, 2017). So, the aim of our work was to instigate the activity of antioxidant system under the influence of stable complexes of polymers based on poly(VEP-co-GMA)-graft-mPEG, poly(PEGMA), and poly(PEGMA-co-DMM) with poorly water-soluble substance BF1.

Earlier, it was reported that thiazole derivative BF1 demonstrated a high cytotoxic action towards several tumor cell lines, increased the level of SOD, while the activity of GPX and CAT decreased (Finiuk et al., 2017; Shalai et al., 2019). It was found that under the action of substances BF1 in complex with all PEG-containing polymers based on poly(VEP-co-GMA)-graft-mPEG(Th1), poly(PEGMA) (Th3) and poly(PEGMA-co$\mathrm{DMM}$ ) (Th5) the activity of SOD significantly increased versus control, while, PCs increased the significance of BF1 influence compared to pure substance from $P<0.05$ to $\mathrm{P}<0.01$. Therefore, BF1 in complex with $\mathrm{PCs}$ directly or indirectly activated SOD activity in lymphoma cells that may lead to the accumulation of $\mathrm{H}_{2} \mathrm{O}_{2}$, which is toxic for tumor cells and can cause DNA breaks, apoptosis and reduce the intensity of glycolysis. Thus, an elevated level of hydrogen peroxide is an early and crucial step towards complexes-induced cancer cell death. A large amount of $\mathrm{H}_{2} \mathrm{O}_{2}$, which was formed due to an increased activity of SOD, was inactivated by important AOC enzymes - KAT and GPX. The affinity of GPX for $\mathrm{H}_{2} \mathrm{O}_{2}$ is higher than that of catalase, so the first enzyme functions more effectively at low concentrations of hydrogen peroxide, while at high concentrations - the key role belongs to the catalase. According to the obtained results, the level of CAT and GPX activity reduced under the effect of all investigated complexes compared to control and were equal versus pure BF1 effect. PEG-PCs improved the significance of BF1 influence on the investigated enzymes in NK/Ly cells compared to pure thiazole derivative from $P<0.05$ to $P<0.01$. Also, there were no significant changes in the activity of all enzymes of antioxidants defense under the influence of any PEGcontaining polymeric carriers.

Thus, thiazole derivative BF1 in complex with PEG-containing polymeric carriers (Th2, Th12; Th4, Th14; Th6 and Th16) significantly changed the activity of the antioxidant defense system. Complexes Th2, Th12 and Th4 increased the significance of BF1 influence on lymphoma cells, while pure PCs did not affect the level of the antioxidant defense system enzymes.

\section{COMPLIANCE WITH ETHICAL STANDARDS}

Conflict of Interest: The authors declare that the research was conducted in the absence of any commercial or financial relationships that could be construed as a potential conflict of interest.

Human Rights: This article does not contain any studies with human subjects performed by any of the authors.

Animal studies: All international, national and institutional guidelines for the care and use of laboratory animals were followed.

ISSN 1996-4536 (print) • ISSN 2311-0783 (on-line) • Біологічні Студії / Studia Biologica • 2021 • Том 15 / № 4 • C. 37-48 


\section{AUTHOR CONTRIBUTIONS}

Conceptualization, [M.V.P.]; methodology, [M.V.P.; Ya.R.Sh.]; validation, [M.V.P.; S.M.M.; Ya.R.Sh.]; formal analysis, [M.V.P.; S.M.M.].; investigation, [M.V.P.; Ya.R.Sh.]; resources, [M.V.P.; N.O.M; O.S.Z.]; data curation, [A.M.B.]; writing - original draft preparation, [M.V.P.]; writing - review and editing, [M.V.P.; A.M.B. ]; visualization, [M.V.P.]; supervision, [S.N.O.]; project administration, [A.M.B.]; funding acquisition, [-].

All authors have read and agreed to the published version of the manuscript.

\section{REFERENCES}

Alimoradi, H., Greish, K., Barzegar-Fallah, A., ALshaibani, L., \& Pittalà, V. (2018). Nitric oxidereleasing nanoparticles improve doxorubicin anticancer activity. International Journal of Nanomedicine, Volume 13, 7771-7787. doi:10.2147/ijn.s187089

Crossref $\bullet$ PubMed $\bullet$ PMC $\bullet$ Google Scholar

Amreddy, N., Babu, A., Muralidharan, R., Panneerselvam, J., Srivastava, A., Ahmed, R., Mehta, M., Munshi, A., \& Ramesh, R. (2018). Recent advances in nanoparticle-based cancer drug and gene delivery. Advances in Cancer Research, 115-170. doi:10.1016/bs.acr.2017.11.003 Crossref $\bullet$ PubMed $\bullet$ PMC $\bullet$ Google Scholar

Dadwal, A., Baldi, A., \& Kumar Narang, R. (2018). Nanoparticles as carriers for drug delivery in cancer. Artificial Cells, Nanomedicine, and Biotechnology, 46(sup2), 295-305. doi:10.1080/ 21691401.2018.1457039

Crossref $\bullet$ PubMed $\bullet$ Google Scholar

De Santana, T. I., Barbosa, M. de O., Gomes, P. A. T. de M., da Cruz, A. C. N., da Silva, T. G., \& Leite, A. C. L. (2018). Synthesis, anticancer activity and mechanism of action of new thiazole derivatives. European Journal of Medicinal Chemistry, 144, 874-886. doi:10.1016/j. ejmech.2017.12.040

Crossref $\bullet$ PubMed $\bullet$ Google Scholar

Finiuk, N. S., Hreniuh, V. P., Ostapiuk, Y. V., Matiychuk, V. S., Frolov, D. A., Obushak, M. D., Stoika R. S., \& Babsky, A. M. (2017). Antineoplastic activity of novel thiazole derivatives. Biopolymers and Cell, 33(2), 135-146. doi:10.7124/bc.00094b

Crossref $\bullet$ Google Scholar

Finiuk, N. S., Popovych, M. V., Shalai, Y. R., Mandzynets', S. M., Hreniuh, V. P., Ostapiuk, Y. V., Obushak, M., Mitina, N. O., Zaichenko, O. S., Stoika, R. S., \& Babsky, A. M. (2021). Antineoplastic activity in vitro of 2-amino-5-benzylthiasol derivative in the complex with nanoscale polymeric carriers. Cytology and Genetics, 55(1), 19-27. doi:10.3103/s0095452721010084 Crossref • Google Scholar

Knop, K., Hoogenboom, R., Fischer, D., \& Schubert, U. S. (2010). Poly(ethylene glycol) in drug delivery: pros and cons as well as potential alternatives. Angewandte Chemie International Edition, 49(36), 6288-6308. doi:10.1002/anie.200902672

Crossref $\bullet$ PubMed $\bullet$ Google Scholar

Korolyuk, M. A., Ivanova, L. I., Mayorova, I. H., \& Tokaryev, V. Ye. (1998). Metod opredeleniya aktivnosti katalazy [A method of determining catalase activity]. Laboratornoe Delo, 1, 16-19. [In Russian]

PubMed • Google Scholar

Kostyuk, V. A., Potapovich, A., I., \& Kovaleva, Zn. V. (1990). Prostoy i chuvstvitelnyy metod opredeleniya aktivnosti superoksiddismutazy, osnovannyy na reaktsii okisleniya kvertsetina [A simple and sensitive method of determination of superoxide dismutase activity based on the reaction of quercetin oxidation]. Voprosy Meditsinskoi Khimii, 36(2), 88-91. [In Russian] PubMed • Google Scholar

ISSN 1996-4536 (print) • ISSN 2311-0783 (on-line) • Біологічні Студії / Studia Biologica • 2021 • Том 15 / № 4 • С. 37-48 
Lee, J.-M., Yoon, T.-J., \& Cho, Y.-S. (2013). Recent developments in nanoparticle-based siRNA deliveryforcancertherapy. BioMedResearch International,2013,1-10.doi:10.1155/2013/782041 Crossref $\bullet$ PubMed $\bullet$ PMC • Google Scholar

Lowry, O., Rosebrough, N., Farr, A. L., \& Randall, R. (1951). Protein measurement with the Folin phenol reagent. Journal of Biological Chemistry, 193(1), 265-275. doi:10.1016/s00219258(19)52451-6

Crossref • PubMed • Google Scholar

Mitina, N. Y., Riabtseva, A. O., Garamus, V. M., Lesyk, R. B., Volyanyuk, K. A., Izhyk, O. M., \& Zaichenko, O. S. (2020). Morphology of the micelles formed by a comb-like PEG-containing copolymer loaded with antitumor substances with different water solubilities. Ukrainian Journal of Physics, 65(8), 670. doi:10.15407/ujpe65.8.670 Crossref $\bullet$ Google Scholar

Moin, V. M. (1986). Prostoĭ i spetsificheskil̆ metod opredeleniia aktivnosti glutationperoksidazy $v$ éritrotsitakh [A simple and specific method for determining glutathione peroxidase activity in erythrocytes]. Laboratornoe Delo, (12), 724-727. [In Russian]

PubMed • Google Scholar

Perillo, B., Di Donato, M., Pezone, A., Di Zazzo, E., Giovannelli, P., Galasso, G., Castoria, G., \& Migliaccio, A. (2020). ROS in cancer therapy: the bright side of the moon. Experimental \& Molecular Medicine, 52(2), 192-203. doi:10.1038/s12276-020-0384-2

Crossref $\bullet$ PubMed $\bullet$ PMC • Google Scholar

Popovych, M. V., Shalai, Y. R., Hreniukh, V. P., Kulachkovskyy, O. R., Mandzynets, S. M., Mitina, N.O., Zaichenko, O. S., \& Babsky, A, M. (2021). Effect of thiazole derivative complexed with nanoscale polymeric carriers on cellular ultrastructure of murine lymphoma cells in vivo. Studia Biologica, 15(2), 15-24. doi:10.30970/sbi.1502.653

Crossref • Google Scholar

Shalai, Y. R., Popovych, M. V., Kulachkovskyy, O. R., Hreniukh, V. P., Mandzynets, S. M., Finiuk, N. S., \& Babsky, A. M. (2019). Effect of novel 2-amino-5-benzylthiazole derivative on cellular ultrastructure and activity of antioxidant system in murine lymphoma cells. Studia Biologica, 13(1), 51-60. doi:10.30970/sbi.1301.591

Crossref • Google Scholar

Shalai, Ya. R., Mandzynets, S. M., Grenyukh, V. P., Finiuk, N. S., \& Babsky, A. M. (2018). Freeradical processes in NK/Ly lymphoma cells and hepatocytes under the effect of thiazole derivative. Bulletin of Problems Biology and Medicine, 1.2(143), 234. doi:10.29254/20774214-2018-1-2-143-234-238

Crossref

Snezhkina, A. V., Kudryavtseva, A. V., Kardymon, O. L., Savvateeva, M. V., Melnikova, N. V., Krasnov, G. S., \& Dmitriev, A. A. (2019). ROS generation and antioxidant defense systems in normal and malignant cells. Oxidative Medicine and Cellular Longevity, 2019, 1-17. doi:10.1155/2019/6175804

Crossref • PubMed • PMC • Google Scholar

Sutradhar, K. B., \& Amin, M. L. (2014). Nanotechnology in cancer drug delivery and selective targeting. ISRN Nanotechnology, 2014, 1-12. doi:10.1155/2014/939378

Crossref $\bullet$ Google Scholar

Wang, H., Agarwal, P., Zhao, G., Ji, G., Jewell, C. M., Fisher, J. P., Lu, X., \& He, X. (2018). Overcoming ovarian cancer drug resistance with a cold responsive nanomaterial. ACS Central Science, 4(5), 567-581. doi:10.1021/acscentsci.8b00050

Crossref $\bullet$ PubMed $\bullet$ PMC $\bullet$ Google Scholar

Wang, L., Du, J., Zhou, Y., \& Wang, Y. (2017). Safety of nanosuspensions in drug delivery. Nanomedicine: Nanotechnology, Biology and Medicine, 13(2), 455-469. doi:10.1016/j. nano.2016.08.007

Crossref $\bullet$ PubMed $\bullet$ Google Scholar

ISSN 1996-4536 (print) • ISSN 2311-0783 (on-line) • Біологічні Студії / Studia Biologica • 2021 • Том 15 / № 4 • C. 37-48 
Zhao, M.-D., Li, J.-Q., Chen, F.-Y., Dong, W., Wen, L.-J., Fei, W.-D., Zhang, X., Yang, P-L., Zhang, X-M., \& Zheng, C.-H. (2019). Co-delivery of curcumin and paclitaxel by "core-shell" targeting amphiphilic copolymer to reverse resistance in the treatment of ovarian cancer. International Journal of Nanomedicine, Volume 14, 9453-9467. doi:10.2147/ijn.s224579 Crossref $\bullet$ PubMed $\bullet$ PMC $\bullet$ Google Scholar

\title{
ЕФЕКТ НОВОСИНТЕЗОВАНОГО ПОХІДНОГО ТІАЗОЛУ \\ ТА ЙОГО КОМПЛЕКСІВ 3 ПОЛІМЕРНИМИ НОСІЯМИ НА АКТИВНІСТЬ ЕНЗИМІВ АНТИОКСИДАНТНОЇ СИСТЕМИ ЗАХИСТУ КЛІТИН МИШАЧОї ЛІМФОМИ
}

\author{
М. В. Попович ${ }^{1}$, Я. Р. Шалай', С. М. Мандзинець \\ Н. Є. Мітіна', О. С. Заїченко르, А. М. Бабський \\ 1 Львівський національний університет імені Івана Франка \\ вул. Грушевського, 4, Львів 79005, Україна \\ 2 Національний університет "Львівська політехніка" \\ пл. Святого Юра, 9, Львів 79013, Україна
}

Обґрунтування. Попередніми дослідженнями встановлено виражену цитотоксичну дію похідних тіазолу в комплексі з полімерними носіями на пухлинні клітини, проте не були цитотоксичними щодо неракових клітин in vitro. Досліджено, що похідні тіазолу в концентраціях 10 і 50 мкМ впливали на прооксидантну й антиоксидантні системи клітин лімфоми in vitro. Мета роботи полягала у дослідженні впливу похідного тіазолу N-(5-benzyl-1,3-thiazol-2-yl)-3,5-dimethyl-1-benzofuran-2carboxamide (BF1) в комплексі з полімерниими носіями poly(VEP-co-GMA)-graftmPEG (Th1), poly(PEGMA) (Th3) та poly(PEGMA-co-DMM) (Th5) на стан антиоксидантної системи клітин NK/Ly in vitro.

Матеріали та Методи. Експерименти виконували на білих мишах-самцях дикого типу з прищепленою лімфомою NK/Ly. Клітини пухлини прищеплювали мишам внутрішньочеревно. Асцит відбирали дренуванням черевної порожнини стерильним шприцом під етерним наркозом на 7-10-ту добу після інокуляції. Досліджувані сполуки BF1, BF1 + Th1 (Th2, Th12), BF1 + Th3 (Th4, Th14), BF1 + Th5 (Th6, Th16) у кінцевій концентрації 10мкМ додавали до дослідних зразків та інкубували впродовж 10 хв і визначали активність ензимів антиоксидантного захисту згідно з методиками, описаними раніше.

Результати. Встановлено, що всі досліджувані комплекси на основі похідного тіазолу BF1 та полімерних носіїв poly(VEP-co-GMA)-graft-mPEG (Th2, Th12), poly(PEGMA) (Th4, Th14) та poly(PEGMA-co-DMM) (Th6, Th16) у концентрації 10 мкM призводили до підвищення активності супероксиддисмутази, натомість знижували активність каталази і глутатіонпероксидази порівняно з контролем. Комплекси Th2, Th12 і Th4 підвищували достовірність впливу речовини BF1 на клітини лімфоми з $\mathrm{P}<0,05$ до $\mathrm{P}<0,01$. Не було зафіксовано жодної достовірної зміни в активності антиоксидантних ензимів за дії вільних полімерних носіїв.

Висновки. Ґрунтуючись на результатах досліджень, встановлили, що полімерні носії в поєднанні з похідним тіазолу BF1 збільшують достовірність впливу речовини на активність системи антиоксидантного захисту клітини лімфоми, а вільні

ISSN 1996-4536 (print) • ISSN 2311-0783 (on-line) • Біологічні Студії / Studia Biologica • 2021 • Том 15 / № 4 • С. 37-48 
полімерні носії не впливають на активність супероксиддисмутази, каталази та глутатіонпероксидази. Отримані дані можуть бути використані у подальших дослідженнях комплексів похідного тіазолу та ПЕГ-вмісних полімерних носіїв як потенційних протипухлинних препаратів.

Ключові слова: лімфома, похідне тіазолу, полімерні носії, поліетиленгліколь, антиоксидантна система захисту 